\title{
Evaluation of abrasive wear of ductile cast iron in a single pass pendulum device
}

\author{
Juan Manuel Vélez ${ }^{\mathrm{a}}$, D.K. Tanaka ${ }^{\mathrm{b}}$, A. Sinatora ${ }^{\mathrm{b}}$, A.P. Tschiptschin ${ }^{\mathrm{c}, *}$ \\ a Mechanical Engineering Department, Universidad Nacional de Colombia, Medellín, Colombia \\ b Mechanical Engineering Department, University of São Paulo, São Paulo, Brazil \\ ${ }^{\mathrm{c}}$ Metallurgical and Materials Engineering Department, University of São Paulo, São Paulo, Brazil
}

\begin{abstract}
The abrasive wear resistance of ductile cast iron with different matrix microstructures (ferrite, pearlite, bainite and martensite) was studied under instrumented single-pass pendulum sclerometry testing. This technique uses only one abrasive particle with known geometry and the abrasive wear event can be isolated, providing fundamental information on the interaction between the particle and the material. The testing conditions selected were equivalent to those usually found on ore processing or dirt excavation machine components. Under these testing conditions high contact stresses and high deformation rates imposes extremely high strains on the material. The abrasion resistance was measured through the specific energy variation as a function of scratch depth that varied between 30 and $150 \mu \mathrm{m}$, corresponding to weight losses between 1 and $12 \mathrm{mg}$.

The results demonstrated that the material response depends on the mechanical properties, on the microstructure and on the depth of penetration. For cast irons with hardness on the order of $300 \mathrm{HV}$ and for scratches up to $60 \mu \mathrm{m}$ deep, the best performance was obtained for pearlitic matrix. For cast irons with hardness on the order of $450 \mathrm{HV}$, the best resistance to abrasive wear was found in the material with bainitic matrix. The ductile iron with hardness $>500 \mathrm{HV}$ and with a tempered martensitic matrix did not present good abrasive wear resistance due to its low toughness. (C) 2001 Elsevier Science B.V. All rights reserved.
\end{abstract}

Keywords: Ductile cast iron; Sclerometry; Abrasive wear

\section{Introduction}

Ductile cast iron shows a wide range of mechanical properties [1] dependent of the chemical composition, microstructure and the shape and distribution of graphite nodules in the matrix. Strength increases with the volume fraction of pearlite in the matrix, but at expenses of ductility and toughness. Martensitic ductile cast iron presents high ultimate tensile stress depending on the tempering temperature with low toughness. Among cast irons, austempered ductile iron presents an excellent combination of mechanical properties [2-4]. For the same toughness, the mechanical resistance of austempered ductile iron can be twice that of the as cast condition.

Austempered ductile cast iron with high hardness (ca. $500 \mathrm{HV}$ ), presents performances comparable to those obtained with martensitic steels, depending on the tribosystem [5,6]. Even the low hardness (ca. 300 HV) ductile austempered cast irons presents good abrasion resistance if strain induced martensite or cold work hardening occur [7].

\footnotetext{
${ }^{*}$ Corresponding author.
}

Zum-Gahr [8] reported greater abrasive wear resistance for lower bainite matrix, when compared to tempered martensitic matrix with the same hardness, under pin on disc test. The high volume fraction of high carbon retained austenite, characteristic of the bainitic structure of these materials, can explain this behavior. The ductility and work hardening capability of this austenite, or its strain induced martensitic transformation, produces a considerable increase in worn surface hardness. Li and Zhou [9] found that the abrasive wear resistance of the ductile cast iron with martensitic matrix also depends on retained austenite volume fraction.

In this work, the abrasion resistance of ductile cast irons with different matrix microstructures (ferrite, pearlite, bainite and martensite) was studied under high contact stresses and strain rates. Instrumented single-pass scratch device (Uppsala pendulum) [10] was used to measure the absorbed specific energy during the scratch test. Since, this technique uses only one counter-body, with known geometry, the abrasive wear event can be isolated, giving basic information such as normal and tangential forces "in situ", between the body and counter-body. 
Table 1

Chemical analysis of the ductile cast iron (wt.\%)

\begin{tabular}{lllllllllll}
\hline $\mathrm{C}$ & $\mathrm{Si}$ & $\mathrm{Mn}$ & $\mathrm{Mg}$ & $\mathrm{P}$ & $\mathrm{S}$ & $\mathrm{Cr}$ & $\mathrm{Sn}$ & $\mathrm{Cu}$ & $\mathrm{Mo}$ & $\mathrm{Ni}$ \\
\hline 3.5 & 2.75 & 0.15 & 0.051 & 0.038 & 0.022 & 0.022 & 0.01 & 0.017 & 0.005 & 0.01
\end{tabular}

\section{Experimental}

\subsection{Materials}

Table 1 presents the chemical composition of the ductile cast iron used. Y-blocks $25 \mathrm{~mm}$ in thick were cast and $60 \mathrm{~mm} \times 10 \mathrm{~mm} \times 10 \mathrm{~mm}$ specimens were machined from the bottom section of the block.

The heat treatments applied to the specimens were selected according to the desired microstructure, as described in Table 2.

Optical microscopy was used to analyze the microstructure. The 2 and 5\% Nital etching was performed for microstructure characterization. X-ray diffraction was carried out to determine the volume fraction of retained austenite, using $\mathrm{Cu} \mathrm{K} \alpha$ wavelength.

\subsection{Apparatus and test methods}

The abrasion resistance experiments were conducted in a modified Charpy pendulum, with maximum capacity of $50 \mathrm{~J}$. A truncated $(0.50 \pm 0.01 \mathrm{~mm}$ side $)$ squared base $40^{\circ}$ pyramid stylus, made of sintered tungsten carbide was used as a scratcher (sclerometry). The specimens were held on a micrometric positioning table, which allowed positioning the specimen precisely in a vertical direction to determine the scratch depth. The initial potential energy was set at $35 \mathrm{~J}$ and the velocity of the scratcher at the point of the first contact was $3.16 \mathrm{~m} / \mathrm{s}$. The system was equipped with strain gages to measure the tangential and normal loads developed during contact between the sample and the scratcher. One of the specimen's faces was metalographically polished before the test. The maximum scratch depth was optically measured at $500 \times$ magnification. The mass loss of the specimen was measured before and after the experiment using an analytical scale with a precision of $0.1 \mathrm{mg}$. The maximum scratch depth varied between 30 and $150 \mu \mathrm{m}$, corresponding to weight losses between 1 and $12 \mathrm{mg}$.

Table 2

Heat treatment cycles for ductile cast iron to obtain the different microstructures $^{\mathrm{a}}$

\begin{tabular}{ll}
\hline Microstructure & Heat treatment \\
\hline Ferrite & $\begin{array}{l}\text { Cooled down to } 700^{\circ} \mathrm{C} \text { (kept in furnace } \\
\text { for } 5 \mathrm{~h} \text { per air cooled) }\end{array}$ \\
Pearlite & Cooled down to room temperature with forced air \\
Bainite & Austempered: $260,280,300,340,370$ and $400^{\circ} \mathrm{C}$ \\
Tempered & Oil quenched/tempered: $200,250,300,350,400$, \\
martensite & $450,500,550$ and $600^{\circ} \mathrm{C}$ \\
\hline
\end{tabular}

${ }^{\text {a }}$ All samples were austenitized at $925^{\circ} \mathrm{C}$ for $2 \mathrm{~h}$.
The specific absorbed energy $(e)$ was calculated from the measured absorbed energy $(E)$ and the removed mass $(W)$ using Eq. (1) [10].

$e=\frac{E}{W}$

This quantity may be associated with the abrasion resistance as it is a measure of the energy necessary to remove a certain amount of material during the wear process.

Vingsbo and Hogmark [11] showed that these curves may be adjusted by an exponential relationship between specific energy and removed mass according to the following equations:

$E(W)=K W^{q}$

$e(W)=K W^{(q-1)}$

\section{Results and discussion}

\subsection{Relation between the specific energy and the amount of weight removed}

The ferritic, bainitic and martensitic specimens were submitted to a batch of scratch tests where the depth of penetration was increased from 30 to $150 \mu \mathrm{m}$ and mass loss and absorbed energy were measured. Mass losses ranged between 1 and $12 \mathrm{mg}$. From the values measured, the specific energies were calculated. Figs. 1-3 show the dependence between specific energy and removed mass for the studied microstructures.

The values of $K$ and $q$, of Eqs. (2) and (3), were determined by exponential fitting of the experimental results presented in Figs. 1-3.

The calculated specific absorbed energies (abrasion resistance) were plotted against the Vickers hardness of each of the studied microstructures. Fig. 4 shows the abrasive wear resistance (specific energy necessary to remove a given

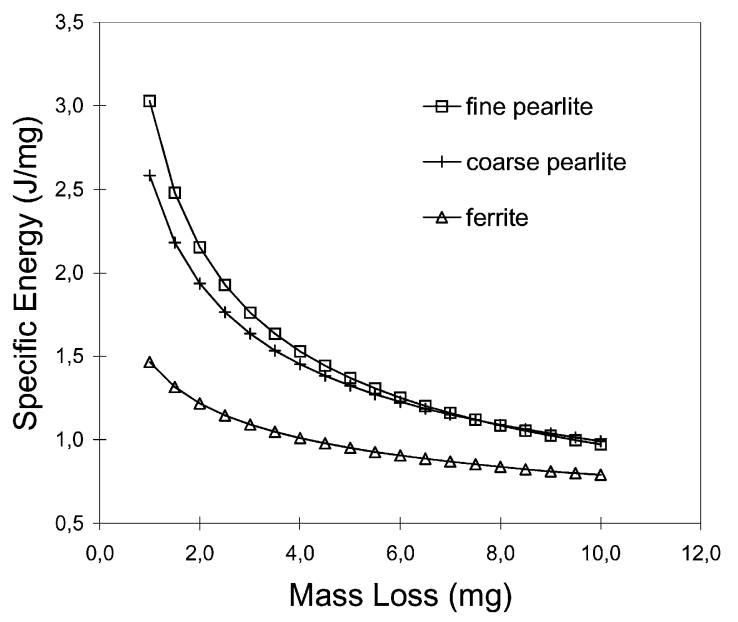

Fig. 1. Specific energy as a function of the mass loss calculated for ductile cast irons with ferritic and pearlitic matrices. 


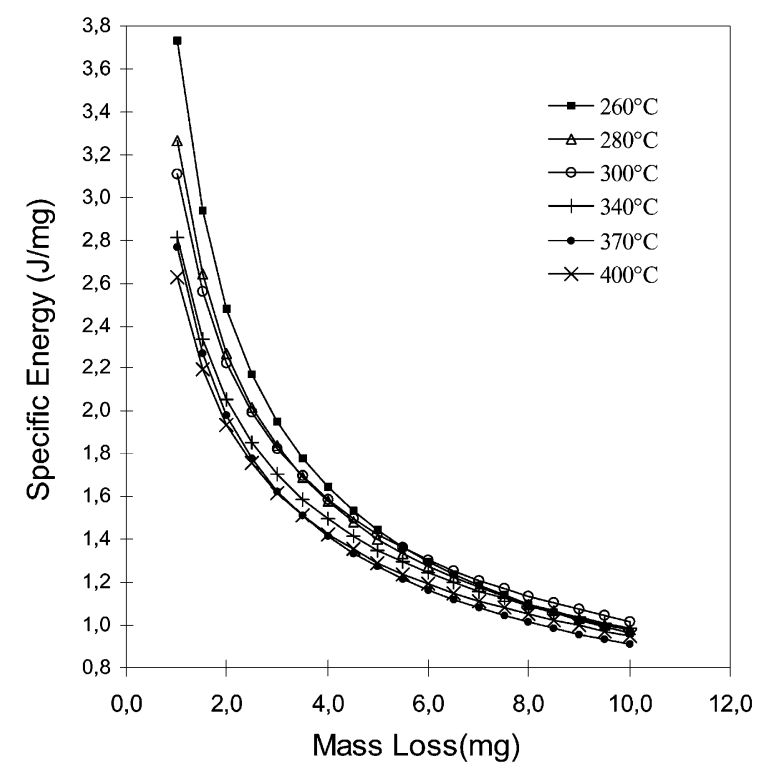

Fig. 2. Specific energy as a function of the weight loss calculated for ductile cast iron with bainitic matrix.

amount of mass) as a function of the cast iron hardness for different microstructures obtained in this work. The relation between abrasive wear resistance and hardness depends on the matrix microstructure and on the depth of the scratch.

As the depth of scratch increases, the differences between abrasive wear resistance for different microstructures and different hardness become less pronounced. Microcutting is the main mechanism responsible for material removal in a scratch test; the energy absorbed being the sum of the energies consumed during:

1. work-hardening of the material;

2. new free surface creation;

3. friction between stylus and ditch surface.

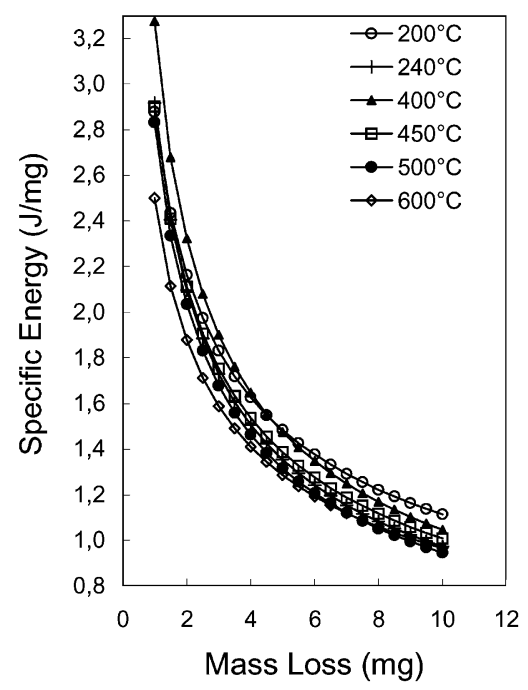

Fig. 3. Specific energy as a function of the weight loss calculated for ductile cast iron with tempered martensitic matrix.

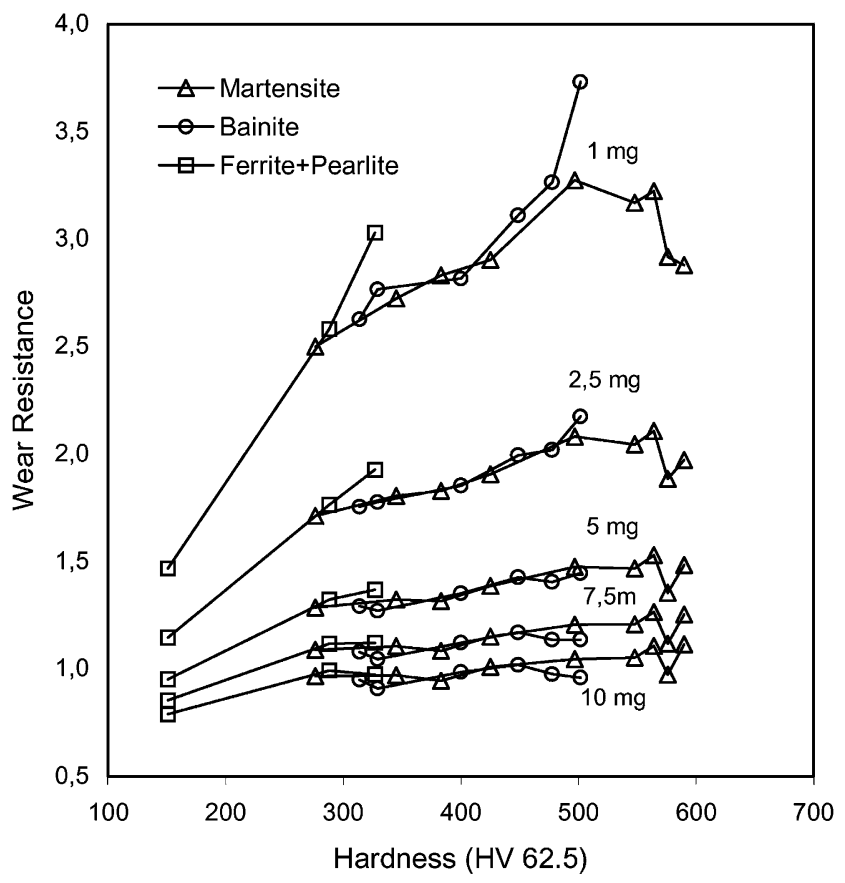

Fig. 4. Variation of the specific energy with hardness for the different microstructures of the ductile cast iron.

Work-hardening is strongly microstructure sensitive while friction and new surface creation are almost microstructure insensitive. The volume fraction of work-hardened material in the debris is inversely proportional to the scratch depth. For shallow scratches the debris is almost entirely work-hardened and this process will be the dominant one determining the energy consumption. As the scratch depth increases only a layer below the material's surface will be work-hardened and the energy consumed will be limited to a negligible threshold value.

On the other hand, friction and the creation of new free surfaces are strongly dependent of the contact area, which varies directly with the scratch depth. Therefore, as the scratch depth increases, there is a strong increase in these two components of the absorbed energy, which are microstructure insensitive. The contact area changes linearly with the depth of the scratch, while the removed mass depends on the volume of the ditch, which increases, with the square of the depth of penetration. Accordingly as the scratch becomes deeper the energy absorbed to remove a certain amount of material decreases as well as the differences between different structures and different hardness.

These results point out the effect of particle size on the abrasive wear: when ductile cast iron is abraded with particles whose size are in the range 30-60 $\mu \mathrm{m}$ the wear resistance is high. Increasing the depth of penetration (particle size) promotes a transition between moderate and severe wear. The differences between different microstructures and different hardness become less prominent. 


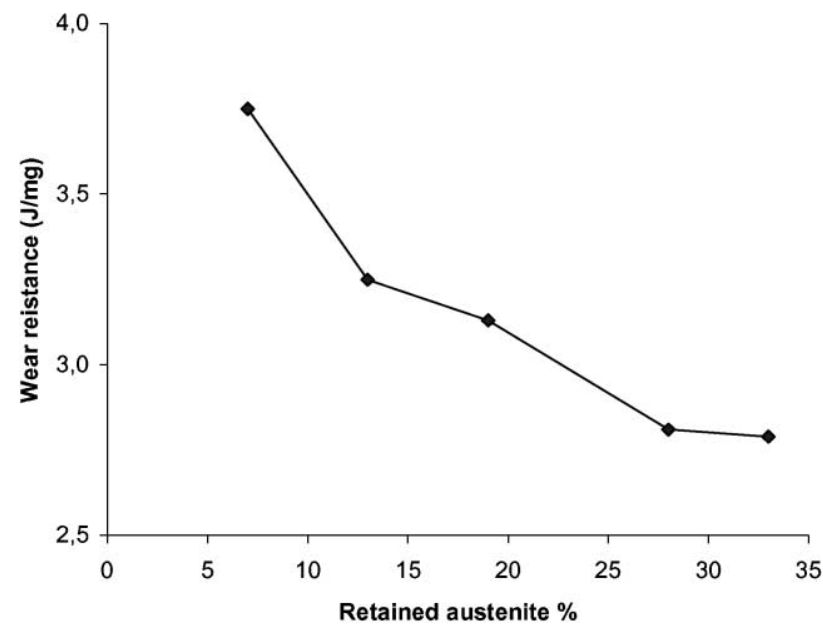

Fig. 5. Variation of the abrasive wear as a function of the retained austenite for ductile cast iron austempered between 260 and $370^{\circ} \mathrm{C}$.

In Fig. 4, it can be seen a linear increase in the wear resistance with hardness for ferritic-pearlitic cast irons. The hardness increase was achieved, in this case, through an increase in cooling rate giving higher amounts of pearlite and lower pearlite spacing. As a consequence, the wear resistance increases with the amount of pearlite, with the volume fraction of carbides and with a decrease in pearlite spacing.

The rate of increase in wear resistance shown by the austempered specimens is higher than the linear rates observed for the ferritic-pearlitic material, being more pronounced for hardness values exceeding $400 \mathrm{HV}$. The microstructures, obtained in austempering treatments, are composed by bainite and retained austenite whose amount increases with austempering temperatures, decreasing the final hardness. The wear resistance changes with the amount of retained austenite as shown in Fig. 5 plotted for scratches $30 \mu \mathrm{m}$ deep, corresponding to a weight loss of $1 \mathrm{mg}$. This result does not agree with those obtained by Zum-Ghar [8], who showed that an increase in the volume fraction of that phase resulted in an increase in the abrasive wear resistance, during pin on disk tests carried out with abrasive papers. The author relates this result to a significant strain hardening of austenite or to strain induced martensitic transformation.

The tempered martensitic specimens showed an increase in wear resistance up to $480 \mathrm{HV}$. Further increases in hardness did not promote an increase in wear resistance, due to a decrease in toughness. Microcracking becomes an important mechanism of wear and larger amounts of debris are taken off by this mechanism. It is worth noting that the tempered martensitic ductile iron with $546 \mathrm{HV}$ (corresponding to a tempering temperature of $350^{\circ} \mathrm{C}$ ), did not show wear rates higher than specimens with $576 \mathrm{HV}$ (corresponding to a tempering temperature of $300^{\circ} \mathrm{C}$ ).

Fig. 6 shows hardness and impact energy values of specimens quenched and tempered between 200 and $600^{\circ} \mathrm{C}$.

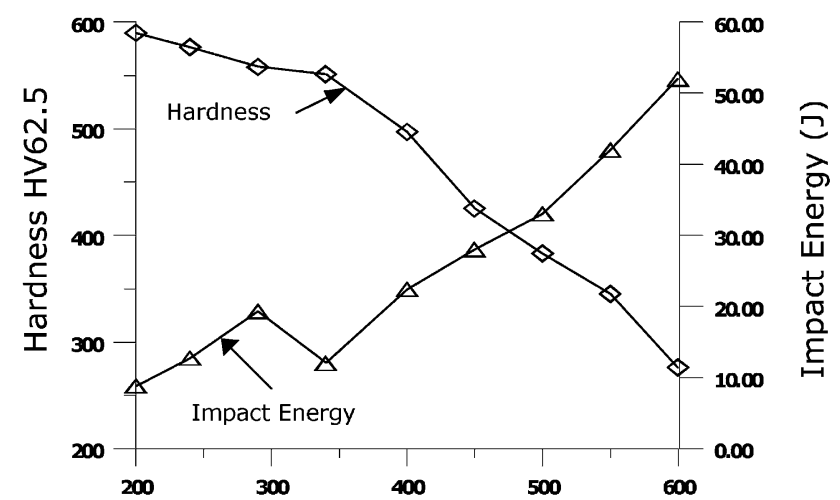

Fig. 6. Variation of hardness $62.5 \mathrm{HV}$ and absorbed energy in Charpy impact test as a function of the tempering temperature for ductile cast iron quenched in oil and tempered.

Hardness decreases continuously with increasing tempering temperature while impact energy increases. At $350^{\circ} \mathrm{C}$, there is a drop in absorbed impact energy corresponding to temper embrittlement.

Hence, the lower wear resistance of the $350^{\circ} \mathrm{C}$ quenched and tempered specimen can be can be assigned to temper embrittlement of the ductile iron. The temper embrittlement temperature is shifted to higher temperatures, when compared with those typical of steels, due to higher silicon contents.

Pearlitic ductile iron containing fine pearlite (280-330 HV) showed greater wear resistance than austempered (upper bainite + retained austenite) or quenched and tempered ductile irons. This result is valid for all the scratch depths studied although it is more pronounced for the scratches 30 and $60 \mu \mathrm{m}$ deep. This result suggests that retained austenite does not improve the material performance under the conditions found in the tribosystem selected for this work.

Lower bainite austempered irons (austempering temperatures in the range $260-300^{\circ} \mathrm{C}$ and hardness between 450 and $500 \mathrm{HV}$ ) showed greater wear resistance than quenched and tempered irons of the same hardness (tempering temperature between 400 and $450^{\circ} \mathrm{C}$ ), when scratches $30 \mu \mathrm{m}$ in depth were performed.

For hardness in the range between 330 and $430 \mathrm{HV}$, there were no significant differences in the wear resistance of ductile cast irons with bainitic or martensitic matrices, independently of the depth of penetration.

Zum-Gahr [8] found a continuous increase in the abrasion resistance of ductile cast iron with tempered martensitic matrix with hardness from 400 to $900 \mathrm{HV}$. These results disagree with those obtained in the present work, in which the wear resistance decreased for hardness values $>480 \mathrm{HV}$. It is worthwhile mentioning that Zum-Gahr [8] used alumina abrasive particles with sizes between 60 and $190 \mu \mathrm{m}$ and low contact pressure $(0.71 \mathrm{MPa})$. Furthermore, the stress states in both systems are quite different. In such a system, 
the relative importance of the different micromechanisms of wear changes necessarily producing scratches with reduced depth in the surface.

\section{Conclusions}

1. Single pass scratch test can be used as a laboratory tool for ranking different ductile cast irons in relation to its abrasion resistance for applications such as crushing jaws for mining industry.

2. As the depth of scratch increases, the differences between abrasive wear resistance for different microstructures and different hardness become less pronounced.

3. The wear resistance of ferritic-pearlitic ductile irons increases linearly with hardness as a consequence of its dependence on pearlite volume fraction and pearlite spacing.

4. Fine pearlite specimens with hardness ranging between 280 and $330 \mathrm{HV}$ showed higher wear resistance than austempered or quenched and tempered specimens with the same hardness. Lower bainite austempered irons (austempering temperatures in the range $260-300^{\circ} \mathrm{C}$ and hardness between 450 and $500 \mathrm{HV}$ ) showed greater wear resistance than quenched and tempered irons of the same hardness (tempering temperature between 400 and $450^{\circ} \mathrm{C}$ ), when scratches $30 \mu \mathrm{m}$ in depth were performed. For scratches deeper than $100 \mu \mathrm{m}$, the quenched and tempered irons performed better.

5. The wear resistance of austempered ductile irons decreased with increasing amounts of retained austenite in the structure.

6. A decrease in the wear resistance was observed in temper embrittled specimens as a consequence of its lower toughness.
7. The selection of heat treatments and corresponding microstructures for ductile irons depends strongly on the range of abrasive particle sizes being used in the tribosystem.

\section{Acknowledgements}

The authors thanks to FAPESP — Fundação de Amparo à Pesquisa do Estado de São Paulo, process no. 94/5876-8, for financial support.

\section{References}

[1] R. Elliot, Cast Iron Technology, Butherworth, London, 1988.

[2] E. Dorazil, B. Bárta, F. Münsterová, L. Stránsky, A. Huvar, High strength bainitic ductile cast iron, A.F.S. Int. Cast Met. J. 7 (2) (1982) 52-62.

[3] R.B. Gundlach, J.F. Janowak, Austempered ductile iron combines strength with toughness and ductility, Met. Prog. 19 (1985) 25.

[4] J.R. Laub, Cast austempered ductile iron for high strength and long wear, Adv. Mater. Proc. 2 (1994) 41.

[5] R.B. Gundlach, J.F. Janowak, Resistance of austempered ductile iron to abrasive wear, Giesserei Praxis 11 (1987) 171-177.

[6] C.H. Zum-Gahr, How microstructure affects abrasive wear resistance, Met. Prog. 116 (4) (1979) 46-52.

[7] E.P. Fordyce, C. Allen, The dry sliding wear of an austempered spheroidal cast iron, in: Proceedings of the International Conference on Wear of Materials, Vol. 1, Denver, USA, 1989.

[8] K.H. Zum-Gahr, Relation between abrasive wear rate and the microstructure of metals, in: Proceedings of the International Conference on Wear of Materials, Reston, 1983.

[9] C. Li, Q. Zhou, Influence of carbon content of martensitic matrix and retained austenite on wear of martensitic ductile iron, Wear 162-164 (1993) 75-82.

[10] M. Jacobsson, M. Olsson, P. Hedenqvist, O. Vingsbo, Scratch testing, ASM handbook, friction, Wear Tribol. 18 (1995) 430.

[11] O. Vingsbo, S. Hogmark, Single-pass pendulum grooving - a technique for abrasive testing, Wear 1000 (1984) 489. 